Original Research Paper

\title{
Presents the Dynamics at a Basic Anthropomorphic Robot
}

\author{
Relly Victoria Virgil Petrescu and Florian Ion Tiberiu Petrescu \\ ARoTMM-IFToMM, Bucharest Polytechnic University, Bucharest, (CE), Romania
}

\author{
Article history \\ Received: 28-03-2020 \\ Revised: 28-04-2020 \\ Accepted: 04-05-2020 \\ Corresponding Author \\ Relly Victoria Virgil Petrescu \\ ARoTMM-IFToMM, Bucharest \\ Polytechnic University, \\ Bucharest, (CE), Romania \\ Email: rvvpetrescu@gmail.com
}

\begin{abstract}
Serial robots are the most used today and among them, the most common is the basic 3R module, the module that is developed in the vast majority of anthropomorphic serial industrial robots, which today occupies at least $80-90 \%$ of the total industrial robots existing worldwide. One studied the kinematics and the forces in this module in other works, with an emphasis on the inverse kinematics, so that in this paper the authors will deal with the dynamic functioning of this $3 \mathrm{R}$ structure, a basic structure as it could be observed, because the dynamics which represent in fact the actual operation of the entire robotic structure is, therefore, the most important in operation, both for the optimal analysis or design of the robotic structure, as well as for its implementation or maintenance throughout its life. The paper presents the real dynamic functioning of the $3 \mathrm{R}$ structure, the related calculation relationships and the diagrams with the simulation of the real dynamic functioning of the $3 \mathrm{R}$ platform.
\end{abstract}

Keywords: Robots, Mechatronic Systems, Dynamics, 3R System, 3R Basic System, 3R Module, 3R Structure

\section{Introduction}

The basic structure of the anthropomorphic robots used today massively in $80-90 \%$ cases from the industrial robots will be presented briefly, with the highlighting of an original method for determining the kinematics of the basic $3 \mathrm{R}$ module and with highlighting the forces at the basic structure set in the discussion. Some representative examples of calculation will be remembered as results. The paper is a basic one in the field and performs a recapitulation of how the basic anthropomorphic structures $3 \mathrm{R}$ are analyzed or designed correctly and quickly.

Such repeated manipulations of heavy and dangerous objects can be done only with the help of a manipulator, which can be a crane, a specially designed trolley, a complicated robot or a simple manipulator as is the case for the one presented in the paper.

Workers are prevented from using it to get various diseases because of the repeated lifting of heavy objects. In the past, an interior crane built on different systems walks through the respective hall to carry the heavy objects.

High-performance machine monitoring robots make a variety of operations efficient, such as sand casting, injection molding, cutting, machining and assembly of small parts.

Top providers should have solutions for every production scenario imaginable, from the smallest to the largest and in any cell configuration. It should also offer a full range of local and international support services available as soon as you need them.

Compact and equipped with up to six axes, certain types of robots are perfectly suited for the surveillance of small autonomous cells. In addition, their powerful controller can control the entire cell, as well as additional peripheral axes (Fig. 1).

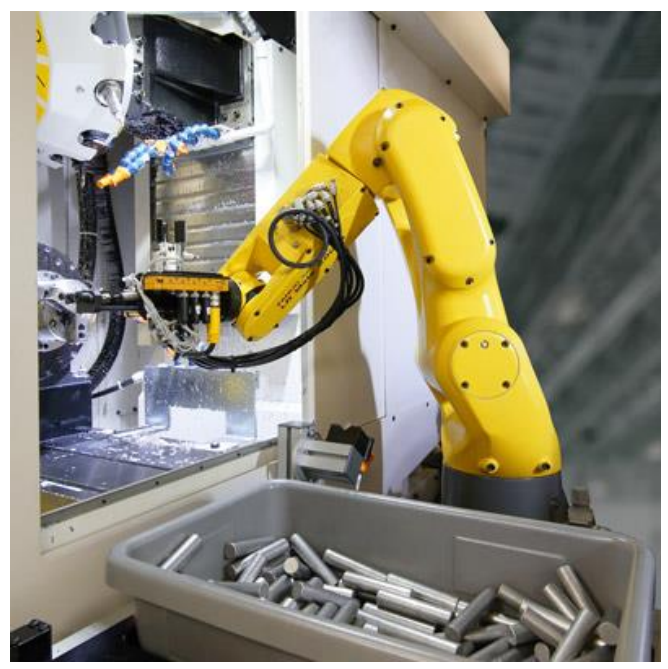

Fig. 1: Compact and equipped with up to six axes, certain types of robots are perfectly suited for the surveillance 
Since space is already limited in most production units, many machine-monitoring robots have a small footprint. They also have standard equipment for protection against water and dust and the cables are drawn through the joint, so as not to be exposed to dangers. Some manufacturers also offer small models that are installed in the machine tool (Fig. 2).

One can use robots for a variety of additional cellrelated operations, such as quality control, specification checking and surface inspection (Fig. 3).

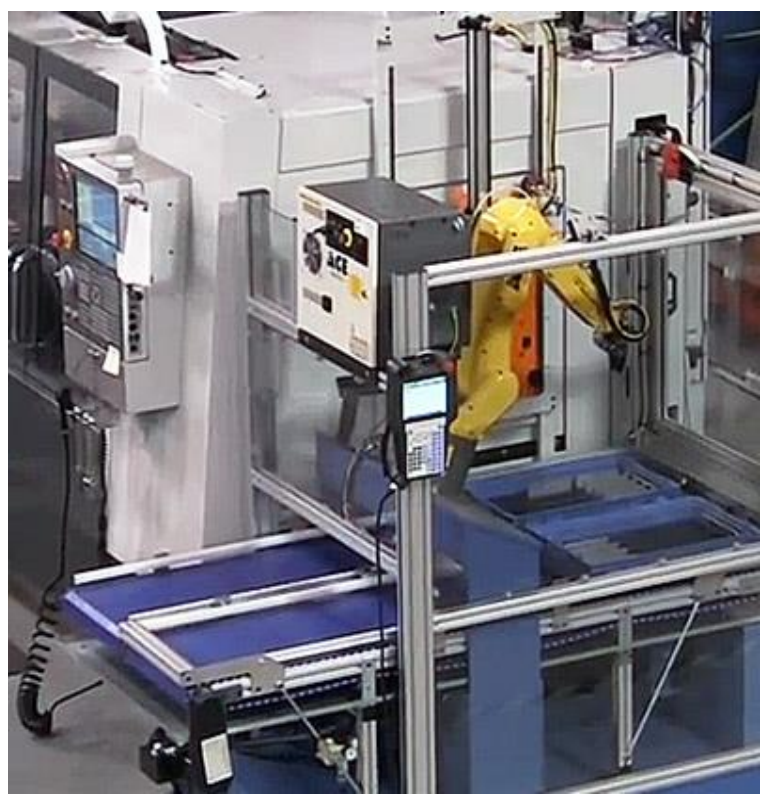

Fig. 2: Compact solutions

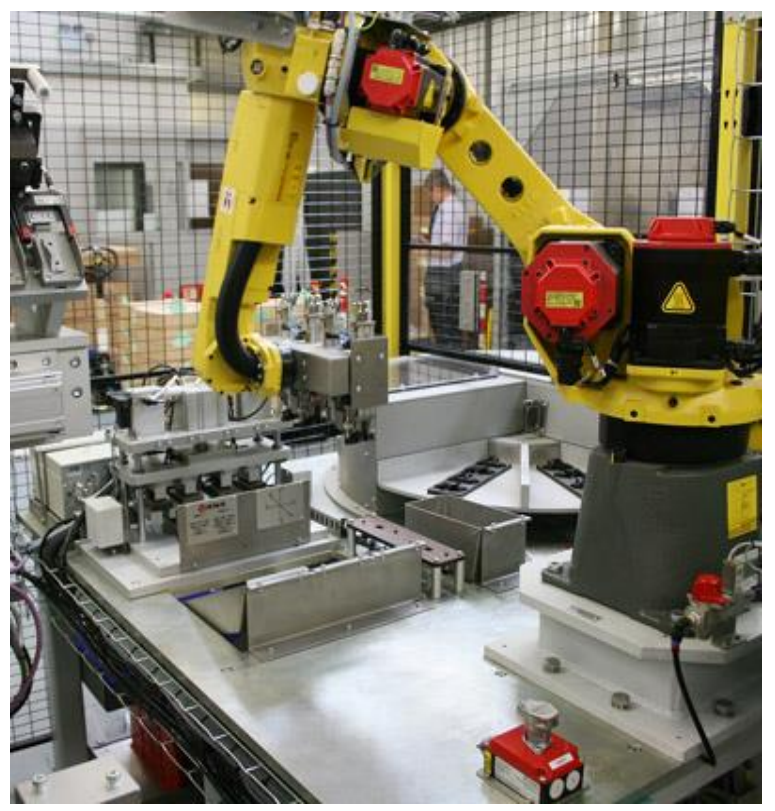

Fig. 3: Use of robots in a variety of industrial operations
Due to the wide range of options for installing instrument replacement stations, including suspended mounting, some types of robots can be used for very efficient instrument replacement. Because they can work with a wide variety of tools, these models can handle any number of instruments, regardless of their weight (Fig. 4).

Robots are priceless when it comes to injection molding. From the disassembly of the parts to the cutting of the screws, unloading, labeling, laser treatment and adding inserts, they increase the efficiency in a variety of operations and prevent the risk of damage (Fig. 5).

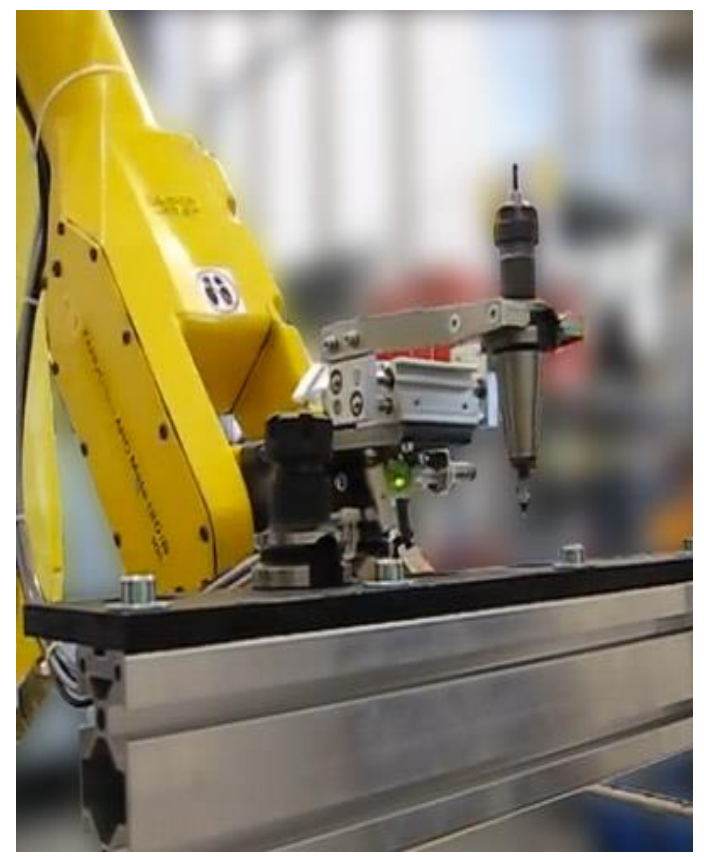

Fig. 4: Faster tool changes

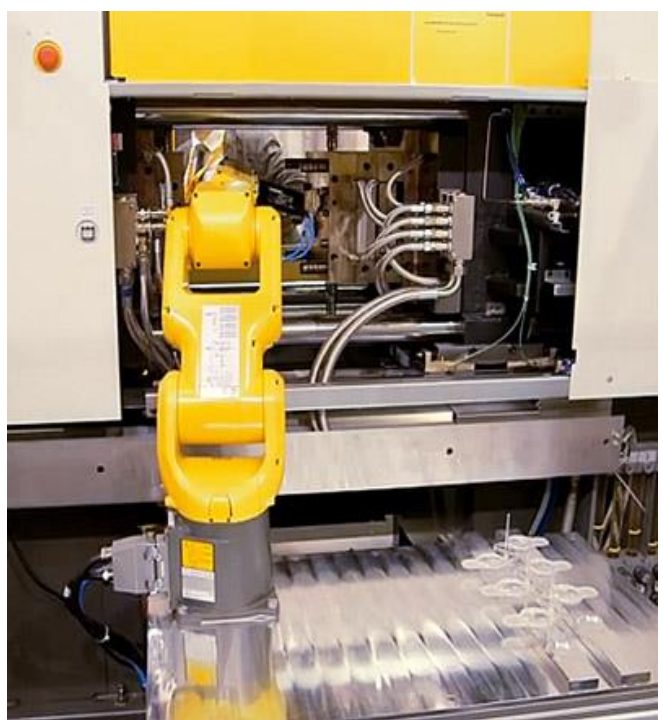

Fig. 5: Injection molding 
With a range of rail, floor, wall and ceiling mount options to save space and expand your robot's workspace, some robot models are ideally suited for multi-tool monitoring - improving your performance and maximizing production time (Fig. 6).

To speed up processes involving containerized parts, container selection solutions based on visual detection allow robots to identify, select and load parts from a container. Sometimes improving 99.97 percent operating times, this technology dramatically accelerates even the most complicated of the selection operations (Fig. 7).

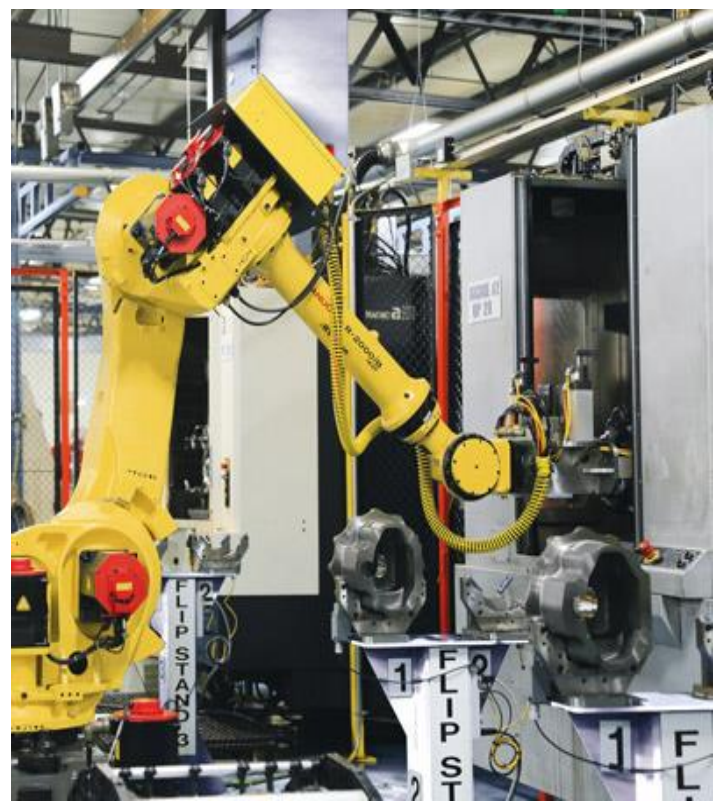

Fig. 6: Load more machinery

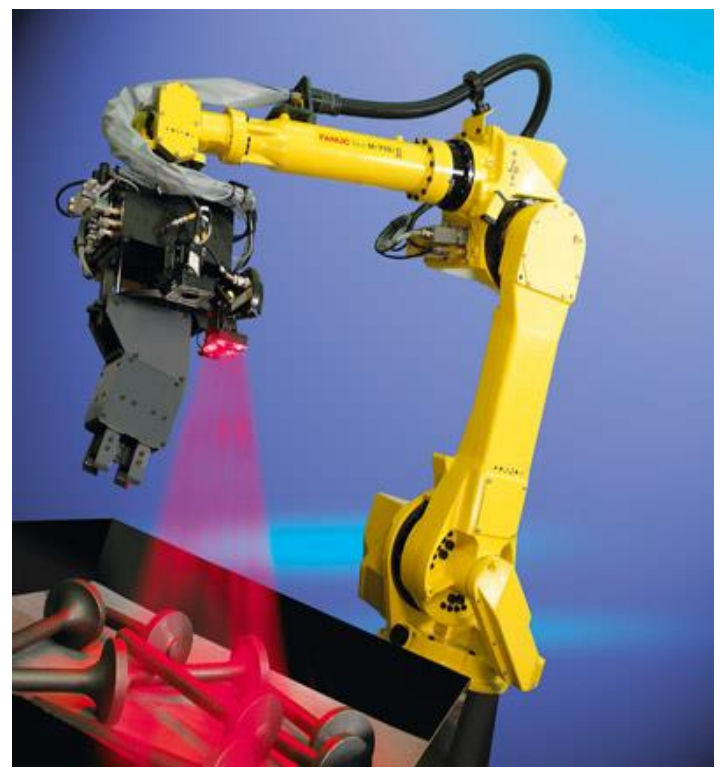

Fig. 7: Randomly load objects quickly
Machine surveillance is an operation that many people are not willing to do. In contrast, quality robots provide $720 \mathrm{~h}$ of perfect production, multiple operations between cells, loading and unloading parts and the ability to connect up to eight machines (Fig. 8).

Extremely lightweight and compact, dedicated monitoring robots available from some manufacturers have been created specifically for high-speed applications such as machine monitoring. Due to the compact arms, the protected harness and the $7 \mathrm{~kg}$ payload, these experts are ideal for production operations that require access to small spaces and where maneuver space is reduced (Fig. 9).

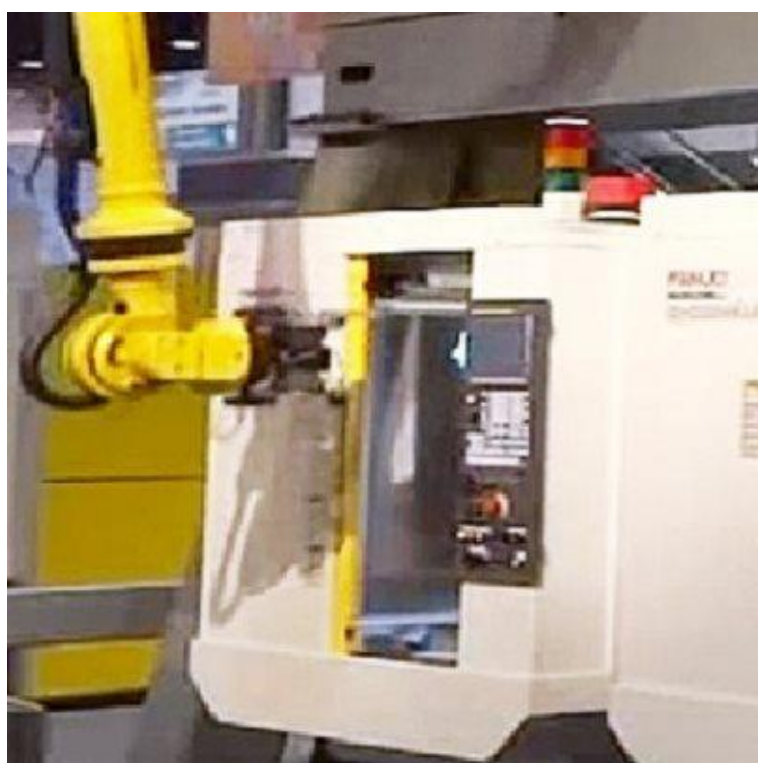

Fig. 8: Fully automated processing

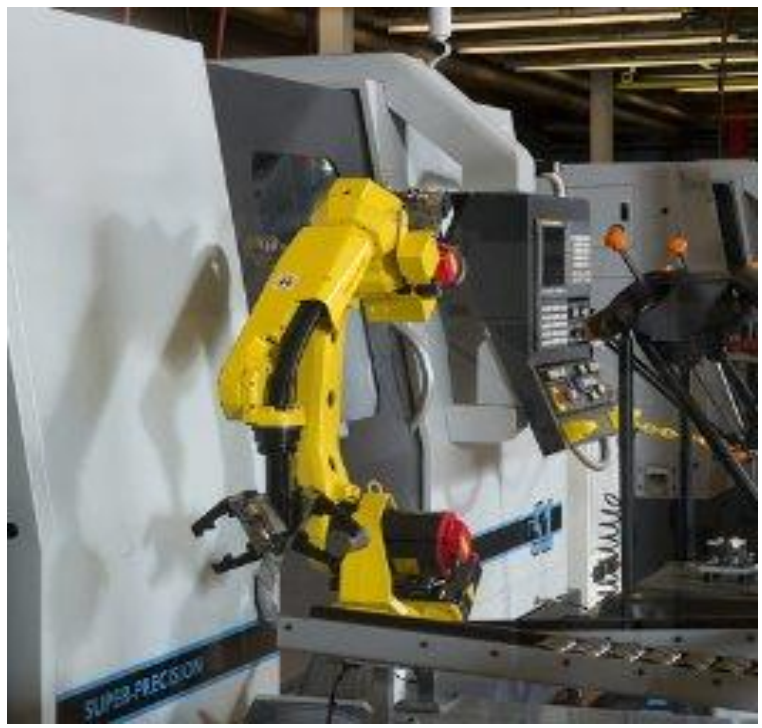

Fig. 9: Experts in machinery supervision 


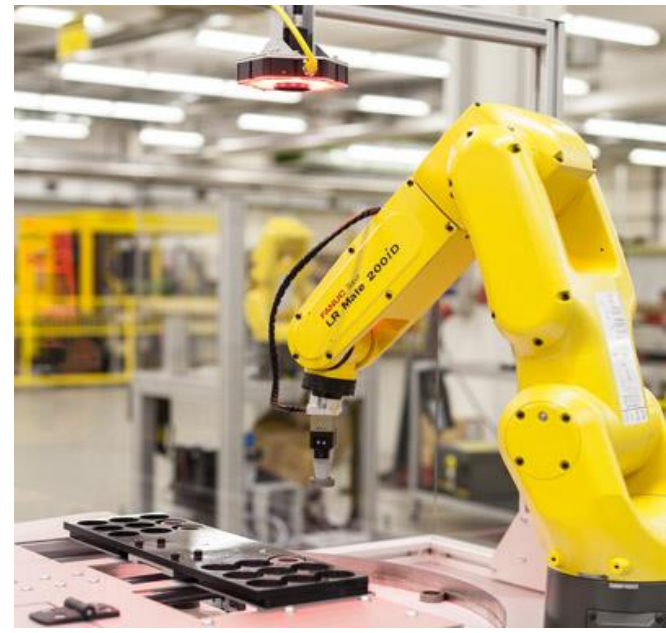

Fig. 10: Expand your visual ability

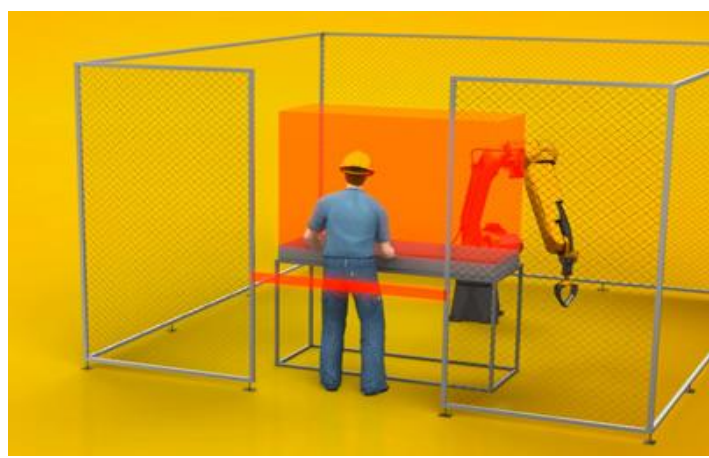

Fig. 11: Great security but invisible

Manufacturers with proven expertise in the field of visual detection systems can equip robots with intelligent visual detection options, which enable a wide range of machine surveillance operations. Options often include 2D visual detection for track location, 3D visual detection for track detection, positioning and orientation, line tracking for conveyors and area sensors for sorting boxes (Fig. 10).

On robots equipped with an optical scanner, the innovative security software provided by some manufacturers allows you to forgo the traditional constraints that take up a lot of space, such as fences and safety hardware. Instead, this feature prevents the robot from accessing specific areas and, by slowing it down, allows the operator to enter the workspace without interrupting production (Fig. 11).

In the case of operations involving multiple processes, the best robots quickly replace the claws to maximize production time (Fig. 12).

A full range of flexible standalone solutions makes machine monitoring robots a very viable option for small businesses (Fig. 13).

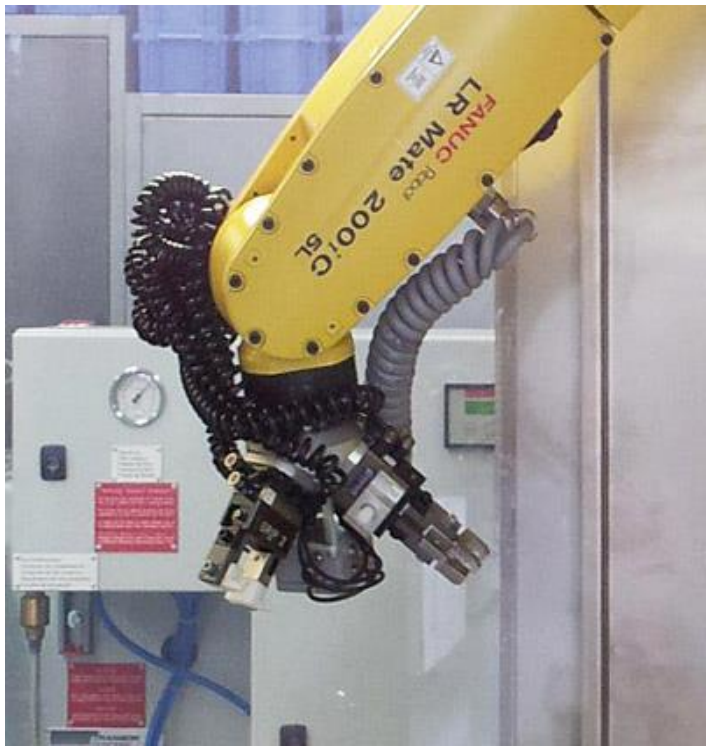

Fig. 12: Change the claws quickly

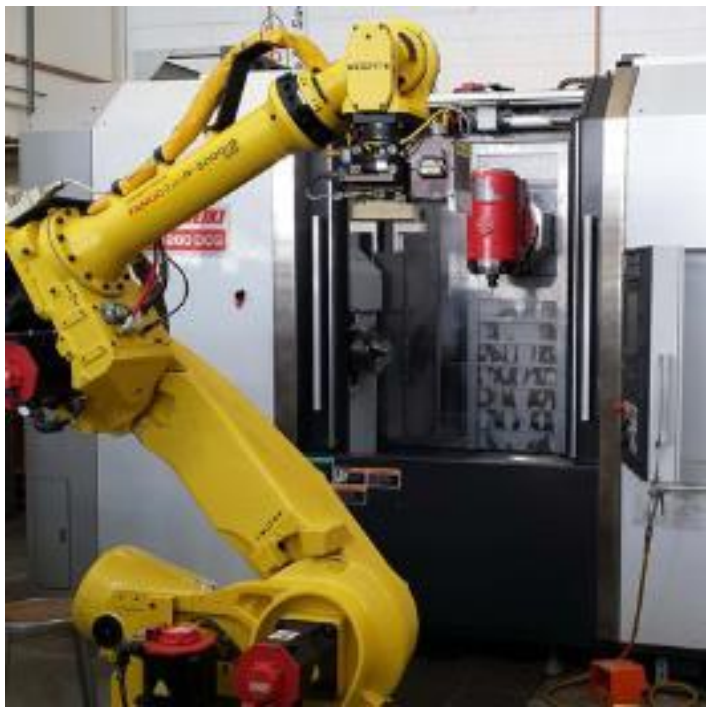

Fig. 13: A full range of flexible standalone solutions makes machine monitoring robots a very viable option for small businesses. Being cheaper and easier to use than you can imagine, they offer significant benefits even for small production cycles

Being cheaper and easier to use than you can imagine, they offer significant benefits even for small production cycles. This is especially the case where the tedious, dirty and dangerous nature of manual surveillance of machines makes it difficult to find and retain manual operators. In addition, after they are created, machine monitoring programs can be restored from memory whenever new commands are received. We can firmly state that today Fanuc robots are respected as the world's number one leading company as 
well as at the beginning of the global robotization of the years 1970-1980. How to analyze or design these robots today indispensable, how to be selected, then implemented and maintained, will be seen from the rapid study carried out in this paper (Antonescu and Petrescu, 1985; 1989; Antonescu et al., 1985a; 1985b; 1986; 1987; 1988; 1994; 1997; 2000a; 2000b; 2001; Aversa et al., 2017a; 2017b; 2017c; 2017d; 2016a; 2016b; 2016c; 2016d; Cao et al., 2013; Dong et al., 2013; El-Tous, 2008; He et al., 2013; Lee, 2013; Lin et al., 2013; Liu et al., 2013; Padula and Perdereau, 2013; Perumaal and Jawahar, 2013; Petrescu, 2011; 2012; 2019; Petrescu and Petrescu, 1995a; 1995b; 1997a; 1997b; 1997c; 2000a; 2000b; 2002a; 2002b; 2003; 2005a; 2005b; 2005c; 2005d; 2005e; 2011a; 2011b; 2012a; 2012b; 2013a; 2013b; 2016a; 2016b; 2016c; Petrescu et al., 2009; 2016; 2017a; 2017b; 2017c; 2017d; 2017e; 2017f; 2017g; 2017h; 2017i; 2017j; 2017k; 2017l; 2017m; 2017n; 2017o; 2017p; 2017q; 2017r; 2017s; 2017t; 2017u; 2017v; 2017w; 2017x; 2018a; 2018b; 2018c; 2018d; 2018e; 2018f; Langston, L.S., 2015-2016; Lee, B.J., 2013; Svensson et al., 2004).

\section{Materials and Methods}

The basic structure 3R of Fig. 14 can be studied more easily in the plane (Fig. 15), greatly facilitating the theoretical work and the computational relations especially to the dynamics of the module.
The forces in Fig. 16 have been presented in other works so that although they represent a part of the dynamics of the module they will not be resumed in the present work.

Starting from Fig. 17 which shows the positions of the centers of mass of the module, one can write the dynamic equations of the module $3 \mathrm{R}$ (system 1 ):

$$
\left\{\begin{array}{l}
J^{*} \equiv J_{B}^{*}=J_{G_{2}}+m_{2} \cdot \frac{\dot{x}_{G_{2}}^{2}+\dot{y}_{G_{2}}^{2}}{\omega_{2}^{2}}+J_{G_{3}} \cdot \frac{\omega_{3}^{2}}{\omega_{2}^{2}}+m_{3} \cdot \frac{\dot{x}_{G_{3}}^{2}+\dot{y}_{G_{3}}^{2}}{\omega_{2}^{2}} \\
J^{* \prime} \equiv J_{B}^{* \prime}=\frac{2 m_{2}}{\omega_{2}^{3}} \cdot\left(\dot{x}_{G_{2}} \cdot \ddot{x}_{G_{2}}+\dot{y}_{G_{2}} \cdot \ddot{y}_{G_{2}}\right) \\
+\frac{2 m_{3}}{\omega_{2}^{3}} \cdot\left(\dot{x}_{G_{3}} \cdot \ddot{x}_{G_{3}}+\dot{y}_{G_{3}} \cdot \ddot{y}_{G_{3}}\right)+\frac{2 J_{G_{3}}}{\omega_{2}^{3}} \cdot \omega_{3} \cdot \varepsilon_{3} \\
\omega_{2}^{*}=\sqrt{J_{m e d}^{*}} \cdot \frac{\omega_{2}}{\sqrt{J^{*}}} \\
\varepsilon_{2}^{*}=\frac{2 \cdot J_{\text {med }}^{*} \cdot J^{*} \cdot \varepsilon_{2}-J_{m e d}^{*} \cdot J^{* \prime} \cdot \omega_{2}^{2}}{2 \cdot J^{* 2}} \\
J_{C}^{*}=J_{G_{3}}+m_{3} \cdot \frac{\dot{x}_{G_{3}}^{2}+\dot{y}_{G_{3}}^{2}}{\omega_{3}^{2}} \\
J_{C}^{* \prime}=\frac{2 m_{3}}{\omega_{3}^{3}} \cdot\left(\dot{x}_{G_{3}} \cdot \ddot{x}_{G_{3}}+\dot{y}_{G_{3}} \cdot \ddot{y}_{G_{3}}\right) \\
\omega_{3}^{*}=\sqrt{J_{C \text { med }}^{*}} \cdot \frac{\omega_{3}}{\sqrt{J_{C}^{* *}}} \\
\varepsilon_{3}^{*}=\frac{2 \cdot J_{C \text { med }}^{*} \cdot J_{C}^{*} \cdot \varepsilon_{3}-J_{C m e d}^{*} \cdot J_{C}^{* \prime} \cdot \omega_{3}^{2}}{2 \cdot J_{C}^{* 2}}
\end{array}\right.
$$

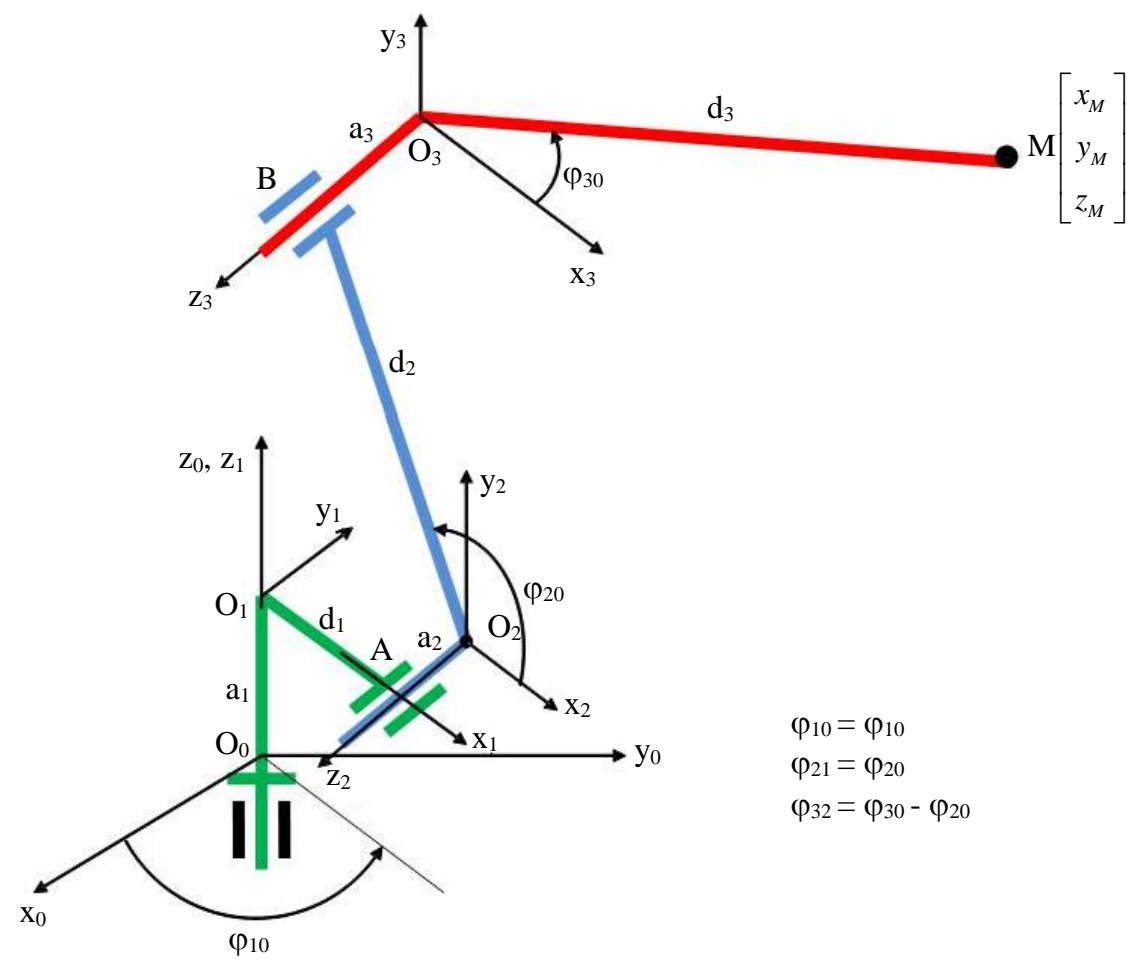

Fig. 14: The spatial basic structure 


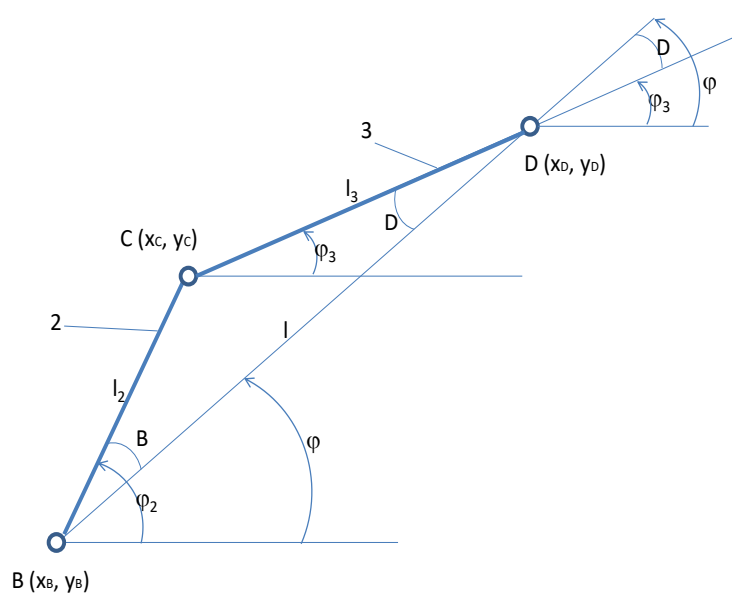

Fig. 15: The planar basic structure

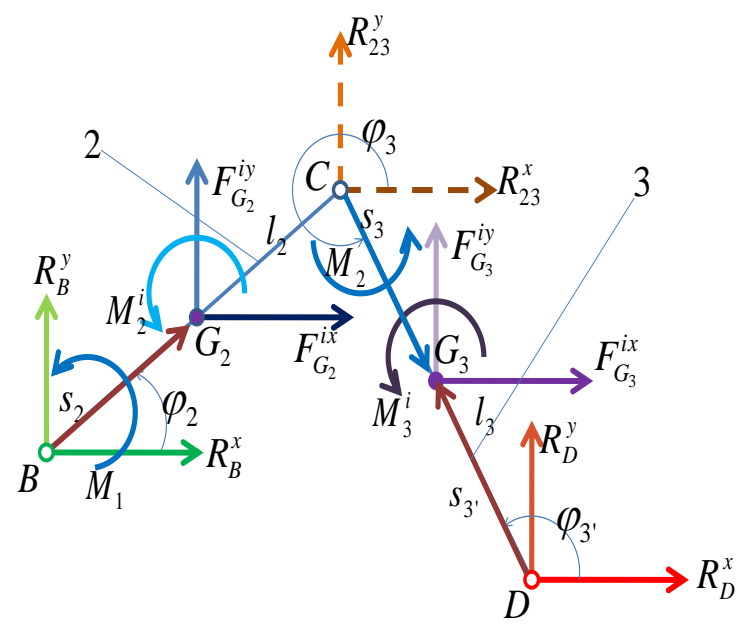

Fig. 16: Forces of the base planar system

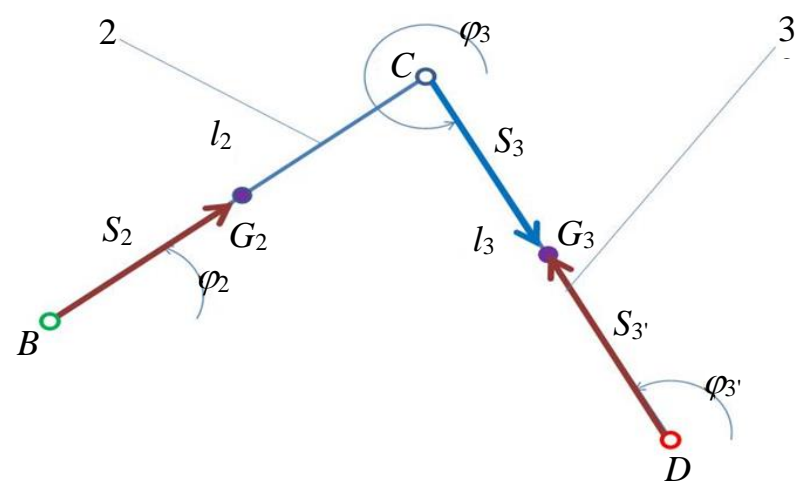

Fig. 17: The centers of mass on the two constituent elements of module 3R 
All the dynamic relationships presented in the relational system (1) are original and are based on the classical dynamic knowledge but also on the original dynamic equations of the authors already presented in other previous works.

Obviously the dynamic values sought are those noted above with a star and it is clear that the element 2 that supports the whole platform 2-3 has a more complex dynamic, whereas the element 3 that acts only on itself has a simpler dynamics closer of known kinematics.

\section{Results and Discussion}

The following will be represented $\mathrm{J} *$ and $\mathrm{J} *$ ', within a calculation example, for element 2 (Fig. 18), which also supports element 3 and the variation of $\mathrm{w}^{*}$ and eps* dynamic (Fig. 19) for the same element 2. Angular velocities are considered constant and known of the two electric motors that operate the planar system discussed so that the kinematic angular accelerations are null, but due to the real dynamic operation for the element 2 there is a variation of the effective angular velocity and therefore a non-zero angular acceleration is born.

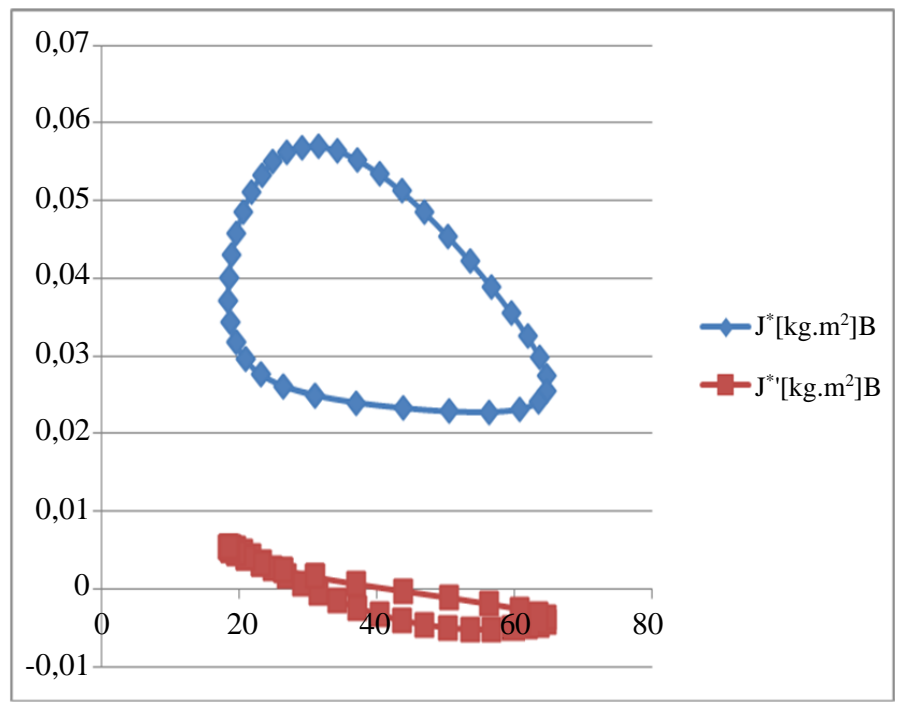

Fig. 18: The moment of inertia of the module 2-3 reduced to the element 2, depending on the positioning angle FI 2 and its derivation according to the same angle FI2

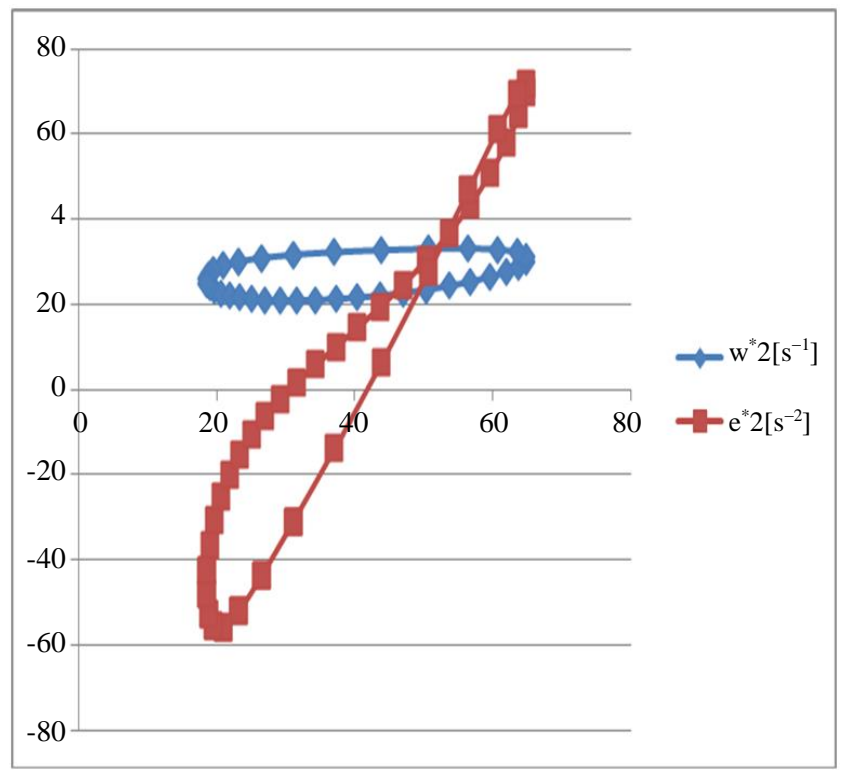

Fig. 19: Variation of the dynamic (real) angular velocity w2* of the element 2 depending on the positioning angle FI 2 and of the dynamic angular acceleration eps $2 *$ also according to the angle FI2 


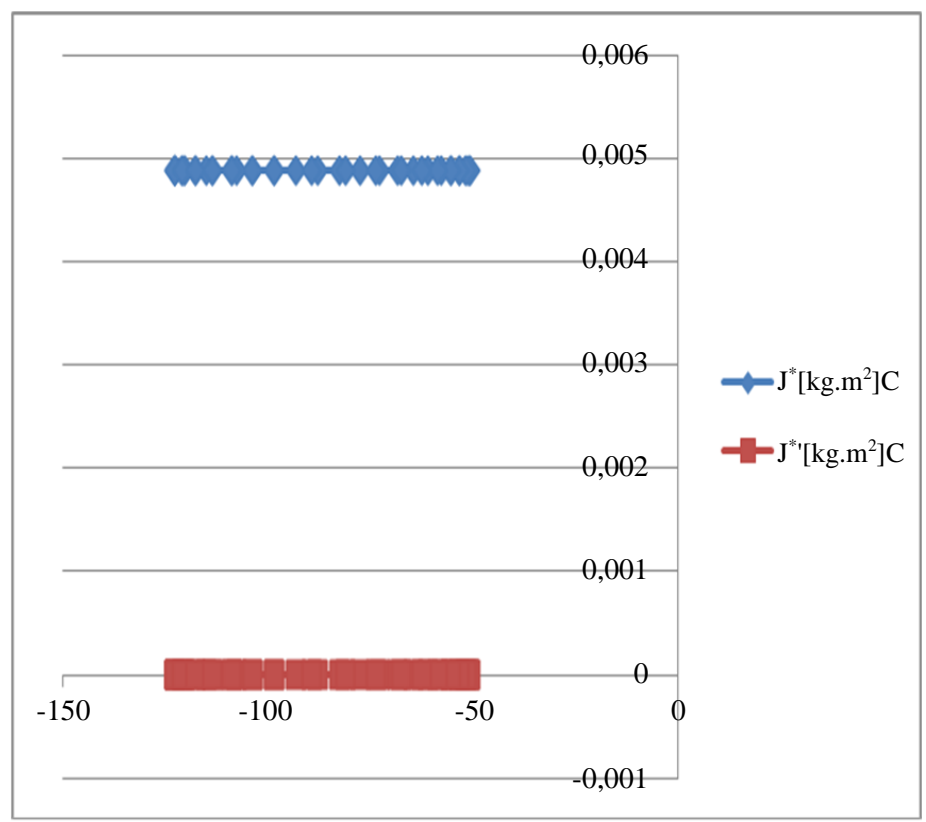

Fig. 20: The moment of inertia of the element 3 reduced to the element 3, depending on the positioning angle FI3 and its derivation according to the same angle FI3

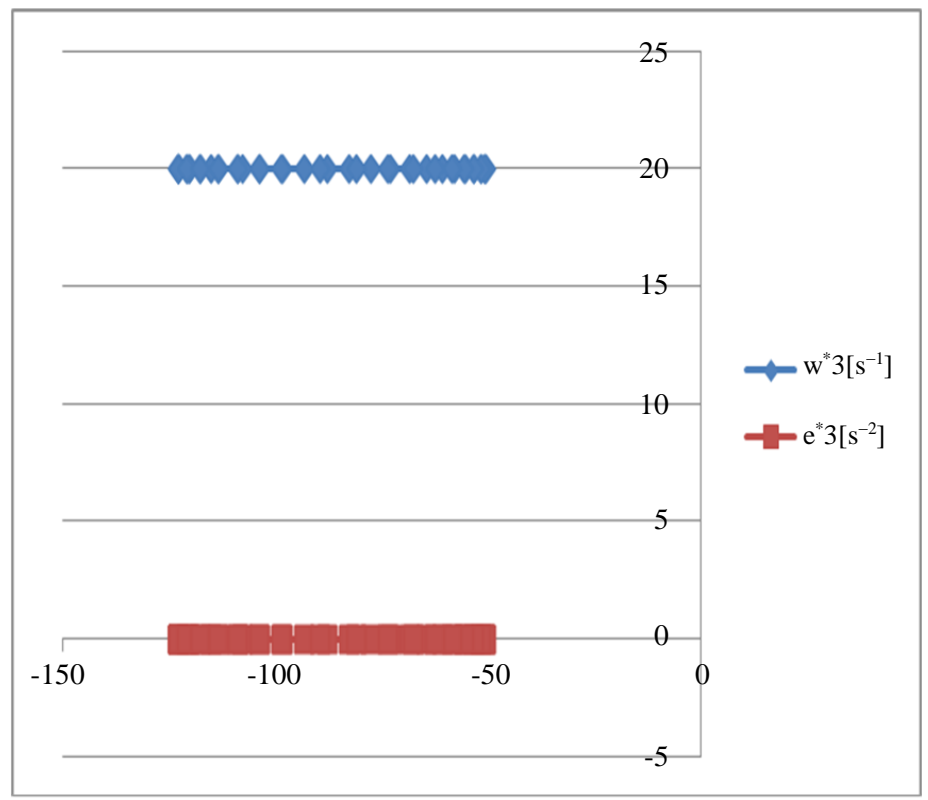

Fig. 21: Variation of the dynamic (real) angular velocity w3* of the element 3 depending on the positioning angle FI 3 and of the dynamic angular acceleration eps $3 *$ also according to the angle FI3

To element 2 the variation is depending on the positioning angle of the element FI2 and on element 3 the input variable is the positioning angle of the element FI3.

At element 3, which in the case of the considered model does not support another additional element, so no more additional loading, dynamics is equivalent to kinematics (Fig. 20-21).

\section{Conclusion}

The real, dynamic functioning of a system is often the most important and from this point of view, the study of the dynamics of the systems becomes extremely important, both in their analysis and in the case of the design and synthesis of the respective system, which is 
valid. and in the serial mobile mechanical systems, the basic module $3 \mathrm{R}$, where for the simplification of the calculations the authors adopted the solution of using the main plan of the system, which will then be rotated around the vertical axis to generate the real spatial motion of the initial module.

All the dynamic relationships presented in the relational system (1) are original and are based on the classical dynamic knowledge but also on the original dynamic equations of the authors already presented in other previous works.

Obviously the dynamic values sought are those noted above with a star and it is clear that the element 2 that supports the whole platform 2-3 has a more complex dynamic, whereas the element 3 that acts only on itself has a simpler dynamics closer of known kinematics.

The following will be represented $\mathrm{J}^{*}$ and $\mathrm{J}^{*}$, within a calculation example, for element 2 (Fig. 18), which also supports element 3 and the variation of $\mathrm{w}^{*}$ and eps* dynamic (Fig. 19) for the same element 2. Angular velocities are considered constant and known of the two electric motors that operate the planar system discussed so that the kinematic angular accelerations are null, but due to the real dynamic operation for the element 2 there is a variation of the effective angular velocity and therefore a non-zero angular acceleration is born.

\section{Acknowledgement}

This text was acknowledged and appreciated by Dr. Veturia CHIROIU Honorific member of Technical Sciences Academy of Romania (ASTR) Ph.D. supervisor in Mechanical Engineering.

\section{Funding Information}

Research contract: Contract number 36-5-4D/1986 from 24IV1985, beneficiary CNST RO (Romanian National Center for Science and Technology) Improving dynamic mechanisms internal combustion engines.

\section{!All these Matters are Copyrighted!}

Copyrights:

- $\quad$ New Aircraft (New Ionic or Beam Engines): no. 548 of 22-04-2010 [cgiywDssin], Aerospace Engineering

- Some Few Specifications About the Doppler Effect to the Electromagnetic Waves: 636 of 28-05-2010 [iEtcaouxxA], physics

- Presenting an Atomic Model and Some Possible Applications in LASER Field: nr. 639 of 29-052010 [yncngrotfo], physics

- Some Applications in LASER Field: no. 718 of 0907-2010 [xeujouincC], physics
- The Energies of Today and Tomorrow: nr. 819 of 30-09-2010 [kbHquxwykr], energy engineering

- Obtaining Energy by the Annihilation of the Matter with Antimatter - The Battle for Energy: nr. 1068 of 13.03.2011 [GfEqpGDzeh], Energy Engineering

\section{Author's Contributions}

All the authors contributed equally to prepare, develop and carry out this manuscript.

\section{Ethics}

This article is original and contains unpublished material. Authors declare that are not ethical issues and no conflict of interest that may arise after the publication of this manuscript.

\section{References}

Antonescu, P. and F.I.T. Petrescu, 1985. An analytical method of synthesis of cam mechanism and flat stick. Proceedings of the 4th International Symposium on Theory and Practice of Mechanisms, (TPM’ 89), Bucharest.

Antonescu, P. and F.I.T. Petrescu, 1989. Contributions to kinetoplast dynamic analysis of distribution mechanisms. Bucharest.

Antonescu, P., M. Oprean and F.I.T. Petrescu, 1985a. Contributions to the synthesis of oscillating cam mechanism and oscillating flat stick. Proceedings of the 4th International Symposium on Theory and Practice of Mechanisms, (TPM' 85), Bucharest.

Antonescu, P., M. Oprean and F.I.T. Petrescu, 1985b. At the projection of the oscillate cams, there are mechanisms and distribution variables. Proceedings of the 5th Conference of Engines, Automobiles, Tractors and Agricultural Machines, (TAM' 58), I-Motors and Cars, Brasov.

Antonescu, P., M. Oprean and F.I.T. Petrescu, 1986. Projection of the profile of the rotating camshaft acting on the oscillating plate with disengagement. Proceedings of the 3rd National Computer-aided Design Symposium in the field of Mechanisms and Machine Parts, (MMP' 86), Brasov.

Antonescu, P., M. Oprean and F.I.T. Petrescu, 1987. Dynamic analysis of the cam distribution mechanisms. Proceedings of the 7th National Symposium on Industrial Robots and Space Mechanisms, (RSM' 87), Bucharest.

Antonescu, P., M. Oprean and F. Petrescu, 1988. Analytical synthesis of Kurz profile, rotating the flat cam. Mach. Build. Rev.

Antonescu, P., F.I.T. Petrescu and O. Antonescu, 1994. Contributions to the synthesis of the rotating cam mechanism and the tip of the balancing tip. Brasov. 
Antonescu, P., F.I.T. Petrescu and D. Antonescu, 1997. Geometrical synthesis of the rotary cam and balance tappet mechanism. Bucharest, 3: 23-23.

Antonescu, P., F.I.T. Petrescu and O. Antonescu, 2000a. Contributions to the synthesis of the rotary disc-cam profile. Proceedings of the 8th International Conference on the Theory of Machines and Mechanisms, (TMM' 00), Liberec, Czech Republic, pp: 51-56.

Antonescu, P., F.I.T. Petrescu and O. Antonescu, $2000 \mathrm{~b}$. Synthesis of the rotary cam profile with balance follower. Proceedings of the 8th Symposium on Mechanisms and Mechanical Transmissions, (MMT'00), Timişoara, pp: 39-44.

Antonescu, P., F.I.T. Petrescu and O. Antonescu, 2001. Contributions to the synthesis of mechanisms with rotary disc-cam. Proceedings of the 8th IFToMM International Symposium on Theory of Machines and Mechanisms, (TMM' 01), Bucharest, ROMANIA, pp: 31-36.

Aversa, R., R.V.V. Petrescu, A. Apicella and F.I.T. Petrescu, 2017a. Nano-diamond hybrid materials for structural biomedical application. Am. J. Biochem. Biotechnol., 13: 34-41.

DOI: $10.3844 / a j b b s p .2017 .34 .41$

Aversa, R., R.V. Petrescu, B. Akash, R.B. Bucinell and J.M. Corchado et al., 2017b. Kinematics and forces to a new model forging manipulator. Am. J. Applied Sci., 14: 60-80.

DOI: 10.3844 /ajassp.2017.60.80

Aversa, R., R.V. Petrescu, A. Apicella, F.I.T. Petrescu and J.K. Calautit et al., 2017c. Something about the V engines design. Am. J. Applied Sci., 14: 34-52. DOI: 10.3844/ajassp.2017.34.52

Aversa, R., D. Parcesepe, R.V.V. Petrescu, F. Berto and G. Chen et al., 2017d. Process ability of bulk metallic glasses. Am. J. Applied Sci., 14: 294-301. DOI: 10.3844/ajassp.2017.294.301

Aversa, R., F.I.T. Petrescu, R.V. Petrescu and A. Apicella, 2016a. Biomimetic FEA bone modeling for customized hybrid biological prostheses development. Am. J. Applied Sci., 13: 1060-1067. DOI: 10.3844/ajassp.2016.1060.1067

Aversa, R., D. Parcesepe, R.V. Petrescu, G. Chen and F.I.T. Petrescu et al., 2016b. Glassy amorphous metal injection molded induced morphological defects. Am. J. Applied Sci., 13: 1476-1482.

DOI: 10.3844 /ajassp.2016.1476.1482

Aversa, R., R.V. Petrescu, F.I.T. Petrescu and A. Apicella, 2016c. Smart-factory: Optimization and process control of composite centrifuged pipes. Am. J. Applied Sci., 13: 1330-1341.

DOI: 10.3844 /ajassp.2016.1330.1341
Aversa, R., F. Tamburrino, R.V. Petrescu, F.I.T. Petrescu and M. Artur et al., 2016d. Biomechanically inspired shape memory effect machines driven by muscle like acting NiTi alloys. Am. J. Applied Sci., 13: 1264-1271.

DOI: $10.3844 /$ ajassp.2016.1264.1271

Cao, W., H. Ding, Z. Bin and C. Ziming, 2013. New structural representation and digital-analysis platform for symmetrical parallel mechanisms. Int. J. Adv. Robotic Sys. DOI: 10.5772/56380

Dong, H., N. Giakoumidis, N. Figueroa and N. Mavridis, 2013. Approaching behaviour monitor and vibration indication in developing a General Moving Object Alarm System (GMOAS). Int. J. Adv. Robotic Sys. DOI: $10.5772 / 56586$

Franklin, D.J., 1930. Ingenious Mechanisms for Designers and Inventors. 1st Edn., Industrial Press Publisher.

He, B., Z. Wang, Q. Li, H. Xie and R. Shen, 2013. An analytic method for the kinematics and dynamics of a multiple-backbone continuum robot. IJARS. DOI: $10.5772 / 54051$

Langston, L.S., 2016. Hot plates. Mechanical Engineering Magazine.

Langston, L.S., 2015. Gas turbines-major greenhouse gas inhibitors. Global Gas Turbine News, Mechanical Engineering Magazine.

Lee, B.J., 2013. Geometrical derivation of differential kinematics to calibrate model parameters of flexible manipulator. Int. J. Adv. Robotic Sys. DOI: $10.5772 / 55592$

Lin, W., B. Li, X. Yang and D. Zhang, 2013. Modelling and control of inverse dynamics for a 5-DOF parallel kinematic polishing machine. Int. J. Adv. Robotic Sys. DOI: 10.5772/54966

Liu, H., W. Zhou, X. Lai and S. Zhu, 2013. An efficient inverse kinematic algorithm for a PUMA560structured robot manipulator. IJARS. DOI: $10.5772 / 56403$

Padula, F. and V. Perdereau, 2013. An on-line path planner for industrial manipulators. Int. J. Adv. Robotic Sys. DOI: 10.5772/55063

Perumaal, S. and N. Jawahar, 2013. Automated trajectory planner of industrial robot for pick-andplace task. IJARS. DOI: 10.5772/53940

Petrescu, F.I.T. and R. Petrescu, 1995a. Contributions to optimization of the polynomial motion laws of the stick from the internal combustion engine distribution mechanism. Bucharest, 1: 249-256.

Petrescu, F.I.T. and R. Petrescu, 1995b. Contributions to the synthesis of internal combustion engine distribution mechanisms. Bucharest, 1: 257-264.

Petrescu, F.I.T. and R. Petrescu, 1997a. Dynamics of cam mechanisms (exemplified on the classic distribution mechanism). Bucharest, 3: 353-358. 
Petrescu, F.I.T. and R. Petrescu, 1997b. Contributions to the synthesis of the distribution mechanisms of internal combustion engines with a Cartesian coordinate method. Bucharest, 3: 359-364.

Petrescu, F.I.T. and R. Petrescu, 1997c. Contributions to maximizing polynomial laws for the active stroke of the distribution mechanism from internal combustion engines. Bucharest, 3: 365-370.

Petrescu, F.I.T. and R. Petrescu, 2000a. Synthesis of distribution mechanisms by the rectangular (Cartesian) coordinate method. Proceedings of the 8th National Conference on International Participation, (CIP' 00), Craiova, Romania, pp: 297-302.

Petrescu, F.I.T. and R. Petrescu, 2000b. The design (synthesis) of cams using the polar coordinate method (triangle method). Proceedings of the 8th National Conference on International Participation, (CIP' 00), Craiova, Romania, pp: 291-296.

Petrescu, F.I.T. and R. Petrescu, 2002a. Motion laws for cams. Proceedings of the International Computer Assisted Design, National Symposium Participation, (SNP' 02), Braşov, pp: 321-326.

Petrescu, F.I.T. and R. Petrescu, 2002b. Camshaft dynamics elements. Proceedings of the International Computer Assisted Design, National Participation Symposium, (SNP' 02), Braşov, pp: 327-332.

Petrescu, F.I.T. and R. Petrescu, 2003. Some elements regarding the improvement of the engine design. Proceedings of the National Symposium, Descriptive Geometry, Technical Graphics and Design, (GTD' 03), Braşov, pp: 353-358.

Petrescu, F.I.T. and R. Petrescu, 2005a. The cam design for a better efficiency. Proceedings of the International Conference on Engineering Graphics and Design, (EGD’ 05), Bucharest, pp: 245-248.

Petrescu, F.I.T. and R. Petrescu, 2005b. Contributions at the dynamics of cams. Proceedings of the 9th IFToMM International Symposium on Theory of Machines and Mechanisms, (TMM' 05), Bucharest, Romania, pp: 123-128.

Petrescu, F.I.T. and R. Petrescu, 2005c. Determining the dynamic efficiency of cams. Proceedings of the 9th IFToMM International Symposium on Theory of Machines and Mechanisms, (TMM' 05), Bucharest, Romania, pp: 129-134.

Petrescu, F.I.T. and R. Petrescu, 2005d. An original internal combustion engine. Proceedings of the 9th IFToMM International Symposium on Theory of Machines and Mechanisms, (TMM' 05), Bucharest, Romania, pp: 135-140.

Petrescu, F.I.T. and R. Petrescu, 2005e. Determining the mechanical efficiency of Otto engine's mechanism. Proceedings of the 9th IFToMM International Symposium on Theory of Machines and Mechanisms, (TMM 05), Bucharest, Romania, pp: 141-146.
Petrescu, F.I.T. and R. Petrescu, 2011a. Mechanical Systems, Serial and Parallel (Romanian). 1st Edn., LULU Publisher, London, UK, pp: 124.

Petrescu, F.I.T. and R. Petrescu, 2011b. Trenuri Planetare. 1st Edn., Createspace Independent Pub., ISBN-13: 978-1468030419, pp: 104.

Petrescu, F.I.T. and R. Petrescu, 2012a. Kinematics of the planar quadrilateral mechanism. ENGEVISTA, 14: 345-348.

Petrescu, F.I.T. and R. Petrescu, 2012b. MecatronicaSisteme Seriale si Paralele. 1st Edn., Create Space Publisher, USA, pp: 128.

Petrescu, F.I.T. and R. Petrescu, 2013a. Cinematics of the 3R dyad. ENGEVISTA, 15: 118-124.

Petrescu, F.I.T. and R. Petrescu, 2013b. Forces and efficiency of cams. Int. Rev. Mechanical Eng.

Petrescu, F.I.T. and R. Petrescu, 2016a. Parallel moving mechanical systems kinematics. ENGEVISTA, 18: 455-491.

Petrescu, F.I.T. and R. Petrescu, 2016b. Direct and inverse kinematics to the anthropomorphic robots. ENGEVISTA, 18: 109-124.

Petrescu, F.I.T. and R. Petrescu, 2016c. Dynamic cinematic to a structure 2R. Revista Geintec-Gestao Inovacao E Tecnol., 6: 3143-3154.

Petrescu, F.I.T., B. Grecu, A. Comanescu and R.V. Petrescu, 2009. Some mechanical design elements. Proceeding of the International Conference on Computational Mechanics and Virtual Engineering, (MVE’ 09), Braşov, pp: 520-525.

Petrescu, F.I.T., 2011. Teoria Mecanismelor si a Masinilor: Curs Si Aplicatii. 1st Edn., CreateSpace Independent Publishing Platform, ISBN-10: 1468015826, pp: 432.

Petrescu, F.I.T., 2012. Cold nuclear fusion. Plasma Phys. Fusion Technol., 44: 100-100.

Petrescu, F.I.T., 2019. About the nuclear particles' structure and dimensions. Comp. Part. Mech., 6: 191-194. DOI: 10.1007/s40571-018-0206-7

Petrescu, F.I.T., A. Apicella, R.V. Petrescu, S.P. Kozaitis and R.B. Bucinell et al., 2016. Environmental protection through nuclear energy. Am. J. Applied Sci., 13: 941-946. DOI: 10.3844/ajassp.2016.941.946

Petrescu, R.V., R. Aversa, B. Akash, R. Bucinell and J. Corchado et al., 2017a. Modern propulsions for aerospace-a review. J. Aircraft Spacecraft Technol., 1: 1-8. DOI: 10.3844/jastsp.2017.1.8

Petrescu, R.V., R. Aversa, B. Akash, R. Bucinell and J. Corchado et al., 2017b. Modern propulsions for aerospace-part II. J. Aircraft Spacecraft Technol., 1: 9-17. DOI: 10.3844/jastsp.2017.9.17

Petrescu, R.V., R. Aversa, B. Akash, R. Bucinell and J. Corchado et al., 2017c. History of aviation-a short review. J. Aircraft Spacecraft Technol., 1: 30-49. DOI: $10.3844 /$ jastsp.2017.30.49 
Petrescu, R.V., R. Aversa, B. Akash, R. Bucinell and J. Corchado et al., 2017d. Lockheed martin-a short review. J. Aircraft Spacecraft Technol., 1: 50-68. DOI: 10.3844/jastsp.2017.50.68

Petrescu, R.V., R. Aversa, B. Akash, J. Corchado and R. Aversa et al., 2017e. Our universe. J. Aircraft Spacecraft Technol., 1: 69-79.

DOI: 10.3844/jastsp.2017.69.79

Petrescu, R.V., R. Aversa, B. Akash, J. Corchado and A. Apicella et al., 2017f. What is a UFO? J. Aircraft Spacecraft Technol., 1: 80-90.

DOI: $10.3844 /$ jastsp.2017.80.90

Petrescu, R.V., R. Aversa, B. Akash, J. Corchado and A. Apicella et al., 2017g. About bell helicopter FCX001 concept aircraft-a short review. J. Aircraft Spacecraft Technol., 1: 91-96.

DOI: $10.3844 /$ jastsp.2017.91.96

Petrescu, R.V., R. Aversa, B. Akash, J. Corchado and A. Apicella et al., 2017h. Home at airbus. J. Aircraft Spacecraft Technol., 1: 97-118. DOI: 10.3844 jastsp.2017.97.118

Petrescu, R.V., R. Aversa, B. Akash, J. Corchado and S.P. Kozaitis et al., 2017i. Airlander. J. Aircraft Spacecraft Technol., 1: 119-148. DOI: $10.3844 /$ jastsp.2017.119.148

Petrescu, R.V., R. Aversa, B. Akash, J. Corchado and A. Apicella et al., 2017j. When boeing is dreaming-a review. J. Aircraft Spacecraft Technol., 1: 149-161. DOI: $10.3844 /$ jastsp.2017.149.161

Petrescu, R.V., R. Aversa, B. Akash, J. Corchado and A. Apicella et al., 2017k. About Northrop Grumman. J. Aircraft Spacecraft Technol., 1: 162-185. DOI: $10.3844 /$ jastsp.2017.162.185

Petrescu, R.V., R. Aversa, B. Akash, J. Corchado and A. Apicella et al., 20171. Some special aircraft. J. Aircraft Spacecraft Technol., 1: 186-203.

DOI: $10.3844 /$ jastsp.2017.186.203

Petrescu, R.V., R. Aversa, B. Akash, J. Corchado and F. Berto et al., 2017m. About helicopters. J. Aircraft Spacecraft Technol., 1: 204-223.

DOI: 10.3844 /jastsp.2017.204.223

Petrescu, R.V., R. Aversa, B. Akash, A. Apicella and F.I.T. Petrescu, 2017n. The modern flight. J. Aircraft Spacecraft Technol., 1: 224-233. DOI: 10.3844 /jastsp.2017.224.233

Petrescu, R.V., R. Aversa, B. Akash, A. Apicella and F.I.T. Petrescu, 2017o. Sustainable energy for aerospace vessels. J. Aircraft Spacecraft Technol., 1: 234-240. DOI: 10.3844/jastsp.2017.234.240

Petrescu, R.V., R. Aversa, B. Akash, A. Apicella and F.I.T. Petrescu, 2017p. Unmanned helicopters. J. Aircraft Spacecraft Technol., 1: 241-248.

DOI: $10.3844 /$ jastsp.2017.241.248
Petrescu, R.V., R. Aversa, B. Akash, A. Apicella and F.I.T. Petrescu, 2017q. Project HARP. J. Aircraft Spacecraft Technol., 1: 249-257. DOI: $10.3844 /$ jastsp.2017.249.257

Petrescu, R.V., R. Aversa, B. Akash, A. Apicella and F.I.T. Petrescu, 2017r. Presentation of Romanian engineers who contributed to the development of global aeronautics-part I. J. Aircraft Spacecraft Technol., 1: 258-271. DOI: $10.3844 /$ jastsp.2017.258.271

Petrescu, R.V., R. Aversa, B. Akash, A. Apicella and A. Apicella et al., 2017s. A first-class ticket to the planet mars, please. J. Aircraft Spacecraft Technol., 1: 272-281. DOI: 10.3844/jastsp.2017.272.281

Petrescu, R.V.V., R. Aversa, S. Li, R. Bucinell, S. Kozaitis and T. Abu-Lebdeh et al., 2017t. Electron dimensions. Am. J. Eng. Applied Sci., 10: 584-602. DOI: 10.3844/ajeassp.2017.584.602

Petrescu, R.V.V., R. Aversa, S. Kozaitis, A. Apicella and F.I.T. Petrescu, 2017u. Deuteron dimensions. Am. J. Eng. Applied Sci., 10: 649-654. DOI: 10.3844/ajeassp.2017.649.654

Petrescu, R.V.V., R. Aversa, S. Kozaitis, A. Apicella and F.I.T. Petrescu, 2017v. Some proposed solutions to achieve nuclear fusion. Am. J. Eng. Applied Sci., 10: 703-708. DOI: 10.3844/ajeassp.2017.703.708

Petrescu, R.V.V., R. Aversa, S. Kozaitis, A. Apicella and F.I.T. Petrescu, 2017w. Some basic reactions in nuclear fusion. Am. J. Eng. Applied Sci., 10: 709-716. DOI: 10.3844/ajeassp.2017.709.716

Aversa, R., R.V.V. Petrescu, A. Apicella, S. Kozaitis and T. Abu-Lebdeh et al., 2017x. Triton for nuclear fusion. Am. J. Eng. Applied Sci., 10: 992-1000. DOI: $10.3844 /$ ajeassp.2017.992.1000

Petrescu, R.V., R. Aversa, A. Apicella and F.I.T. Petrescu, 2018a. Romanian engineering "on the wings of the wind". J. Aircraft Spacecraft Technol., 2: 1-18. DOI: 10.3844/jastsp.2018.1.18

Petrescu, R.V., R. Aversa, A. Apicella and F.I.T. Petrescu, 2018b. NASA data used to discover eighth planet circling distant star. J. Aircraft Spacecraft Technol., 2: 19-30. DOI: 10.3844/jastsp.2018.19.30

Petrescu, R.V., R. Aversa, A. Apicella and F.I.T. Petrescu, 2018c. NASA has found the most distant black hole. J. Aircraft Spacecraft Technol., 2: 31-39. DOI: $10.3844 /$ jastsp.2018.31.39

Petrescu, R.V., R. Aversa, A. Apicella and F.I.T. Petrescu, 2018d. Nasa selects concepts for a new mission to titan, the moon of saturn. J. Aircraft Spacecraft Technol., 2: 40-52.

DOI: 10.3844 jastsp.2018.40.52

Petrescu, R.V., R. Aversa, A. Apicella and F.I.T. Petrescu, 2018e. NASA sees first in 2018 the direct proof of ozone hole recovery. J. Aircraft Spacecraft Technol., 2: 53-64. DOI: 10.3844/jastsp.2018.53.64 
Petrescu, R.V.V., R. Aversa, A. Apicella and F.I.T. Petrescu, 2018f. Modern propulsions for the aerospace industry. Am. J. Eng. Applied Sci., 11: 715-755. DOI: 10.3844/ajeassp.2018.715.755

Petrescu, F.I.T. and K.J. Calautit, 2016a. About nano fusion and dynamic fusion. Am. J. Applied Sci., 13: 261-266. DOI: 10.3844/ajassp.2016.261.266

Petrescu, F.I.T. and K.J. Calautit, 2016b. About the light dimensions. Am. J. Applied Sci., 13: 321-325.

DOI: 10.3844/ajassp.2016.321.325

Svensson, F., A. Hasselrot and J. Moldanova, 2004. Reduced environmental impact by lowered cruise altitude for liquid hydrogen-fuelled aircraft. Aerospace Sci. Technol., 8: 307-320.

DOI: 10.1016/j.ast.2004.02.004

\section{Source of Figures:}

\section{Figure 01:}

https://www.fanuc.eu/ /media/corporate/products/rob ots/lrmate/generic/400x400/fea-ro-ia-lrm-rd-load-

1.jpg? $\mathrm{w}=400$

\section{Figure 02:}

https://www.fanuc.eu/ /media/corporate/products/rob ots/lrmate/generic/400x400/fea-ro-ia-lrm-load-

4.jpg? $\mathrm{w}=400$

Figure 03:

https://www.fanuc.eu/ /media/corporate/products/rob ots/m10/generic/400x400/m-10ia-cell-related-robotbanner.jpg? $\mathrm{w}=400$

Figure 04:

https://www.fanuc.eu/ /media/corporate/products/rob ots/arcmate/generic/400x400/arc-mate-robot-toolchange-banner.jpg? $\mathrm{w}=400$

\section{Figure 05:}

https://www.fanuc.eu/ /media/corporate/products/rob oshot/400x400/robot-unloading-roboshot-machinebanner.jpg? $\mathrm{w}=400$

\section{Figure 06:}

https://www.fanuc.eu/ /media/corporate/products/rob ots/r2000/generic/400x400/fea-ro-ia-r2000-mcload-

4.jpg? $\mathrm{w}=400$

Figure 07:

https://www.fanuc.eu/ /media/corporate/products/rob ots/m710/generic/400x400/m710ia-robot-vision-randombanner.jpg? $\mathrm{w}=400$

\section{Figure 08:}

https://www.fanuc.eu/ /media/corporate/products/rob ots/r2000/generic/400x400/fea-ro-ia-r2000-rd-tend-

1.jpg? $\mathrm{w}=400$

\section{Figure 09:}

https://www.fanuc.eu/ /media/corporate/products/rob ots/m10/generic/400x400/m-10ia-tending-robot-processbanner.jpg?w=264

Figure 10:

https://www.fanuc.eu/ /media/corporate/products/rob ots/lrmate/generic/400x400/fea-ro-ia-lrm200d-vis-

5.jpg? $\mathrm{w}=400$

\section{Figure 11:}

https://www.fanuc.eu/ /media/corporate/products/rob ots/accessories/safety/400x400/dcs-safety-visualizationbanner.jpg?w=400

Figure 12:

https://www.fanuc.eu/ /media/corporate/products/rob ots/lrmate/generic/400x400/fea-ro-ia-lrm200c-

toolchan.jpg?w=400

Figure 13:

https://www.fanuc.eu/ /media/corporate/products/rob ots/r2000/generic/400x400/fea-ro-ia-r2000-mcload6.jpg? $\mathrm{w}=264$

\section{Figure 14-21:}

Made by authors. 